\title{
Aplikasi Penjadwalan Tugas Lapangan Bagi Pegawai Berbasis Badan Pusat Statistik Kota Tangerang
}

\author{
Ajay Supriadi*1 \\ Gerry Ramadhan ${ }^{2}$ \\ Yulia Ningsih ${ }^{3}$ \\ 1,2,3 Program Studi Teknik Informatika Fakultas Sains dan Teknologi Universitas Raharja \\ E-mail: *1 ajay.supriadi@ raharja.info, ${ }^{2}$ gerry@ raharja.info, ${ }^{3}$ yulia.ningsih@ raharja.info
}

\begin{abstract}
Abstrak
Pada Badan Pusat Statistik Kota Tangerang memiliki bagian Tata Usaha yang bertugas untuk membuat sebuah penjadwalan tugas kerja lapangan yang dimana harus dicatat dengan cara manual dan harus mamakan waktu, hingga menjadi kurang efisien dan efektif. Dengan dibuatnya aplikasi penjadwalan berbasis web ini bertujuan membangun sebuah sistem aplikasi yang dapat mengatasi masalah yang terjadi pada Badan Pusat Statistik Kota Tangerang. Peneliti mengumpulkan data dengan cara melakukan observasi, wawancara, dan studi pustaka. Pada penelitian ini penulis menggunakan metode analisa PIECES untuk menganalisa kebutuhan dan menggunakan Unified Modelling Language (UML) sebagai alat bantu untuk membuat rancangan model dan desain. Penelitian ini menghasilkan sebuah aplikasi jadwal tugas lapangan berbasis web yang dibuat dengan $P H P$ sebagai bahasa pemrogramanya dan MySQL sebagai database. Dapat disimpulkan bahwa aplikasi ini memiliki 2 pengguna yaitu Kepala Seksi Tata Usaha sebagai admin yang dimana bertugas dalam mengolah data pegawai dan data jadwal, pegawai dapat melihat jadwal yang telah dibuat oleh admin dan dapat menginput laporan target tugas tersebut.
\end{abstract}

Kata Kunci: Aplikasi, Penjadwalan, Tugas Kerja Lapangan, Web.

\begin{abstract}
The Central Bureau of Statistics, Kota Tangerang has an Administration section that is tasked with scheduling fieldwork which must be recorded manually and must take time, making it less efficient and effective. With the creation of a web-based scheduling application, it aims to build an application system that can solve problems that occur at the Tangerang City Central Statistics Agency. Researchers collected data by making observations, interviews, and literature studies. In this study the authors used the PIECES analysis method to analyze needs and used the Unified Modeling Language (UML) as a tool for making models and designs. This research produces a web-based field assignment schedule application made with PHP as the programming language and MYSQL as the database. It can be concluded that this application has 2 users, namely the Head of Administration as an admin who is in charge of processing employee data and schedule data, employees can see the schedule that has been made by the admin and can input the report on the target assignment.
\end{abstract}

Keywords - Applications, Scheduling, Fieldwork Tasks, Web.

\section{Pendahuluan}


Pemakaian internet sebagai sarana pengolahan informasi kian pesat dan terbukti sangat ampuh, maka tak heran saat ini hampir semua perusahaan dan berbagai organisasi masyarakat mulai membangun sebuah aplikasi website, blog, atau media sosial lainnya guna memanfaatkan hal tersebut. Informasi yang disebarkan pun sangat beragam mulai dari profil perusahaan hingga informasi-informasi yang ditunjukan untuk anggota sebuah lembaga organisasi tersebut.

Badan Pusat Statistik (BPS, dahulu Biro Pusat Statistik), merupakan Lembaga Pemerintah Non Departemen di Indonesia yang mempunyai fungsi pokok sebagai penyedia data statistik dasar, baik untuk pemerintah maupun untuk masyarakat umum, secara nasional maupun regional. Dalam tata strukturnya, BPS langsung dibawah presiden. BPS terbagi kedalam tiga tingkatan, BPS Pusat, BPS Provinsi, dan BPS Kabupaten/ Kota (Badan Pusat Statistik).[1]

Pada saat ini, aplikasi kalender berbasis web sudah dipakai secara luas. Banyak perusahaan dan perguruan tinggi yang menggunakan aplikasi kalender berbasis web[2] untuk mengelola berbagai kegiatan, misalnya menggunakan kalender untuk menjadwal kegiatan akademik, membuat kalender pribadi, hingga untuk mengatur jadwal penugasan. Terutama pada Badan Pusat Statistik kota Tangerang.

Penjadwalan adalah aktivitas perencanaan untuk menentukan kapan dan dimana setiap operasi sebagai bagian dari pekerjaan secara keseluruhan harus dilakukan pada sumber daya yang terbatas, serta pengalokasian sumber daya pada suatu waktu tertentu dengan memperhatikan kapasitas sumber daya yang ada[3].

Dalam proses yang berjalan saat ini Badan Pusat Statistik Kota Tangerang masih harus membuat sebuah kalender besar dalam pengelolaan jadwal penugasan[4] bagi para pegawai yang dimana admin harus membuatnya secara manual lalu mencetak dengan media kertas. Dengan sering terjadinya beberapa masalah seperti, kesalahan dalam melakukan proses penginputan dan bahkan kehilangan buku penjadwalan tersebut.

Pada dasarnya, penelitian ini bertujuan untuk mengembangkan sistem yang ada agar admin bisa dapat lebih cepat dalam proses penginputan dan pengolahan dalam membuat sebuah jadwal penugasan bagi para pegawai dan dapat menerima laporan lebih cepat dan akurat[5].

Perbaikan kualitas data ini telah dimulai dari metodologi yang dirancang oleh Badan Pusat Statistik pusat sampai dengan pengumpulan data di lapangan. Panjangnya proses untuk menghasilkan data berkualitas ini tidak boleh ada satu proses yang terlewatkan. Salah satu proses penting dalam menghasilkan data berkulitas adalah proses pengumpulan data yang dilakukan oleh petugas lapangan melalui kegiatan survei dan sensus.[6]

\section{Metode Penelitian}

\subsection{Metode Analisa PIECES}

Pada metode ini penulis menggunakan metode analisa PIECES yaitu salah satu metode yang digunakan untuk menganalisa sistem dari performance, information, economic, control, efficiency, dan service[7].

1. Performance (kinerja)

Performance atau kinerja merupakan suatu analisis terhadap kemampuan sistem dan menyelesaikan tugas dengan baik.

Tabel I. Performance (kinerja)

\begin{tabular}{|l|l|}
\hline Sistem lama & \multicolumn{2}{|c|}{ Sistem yang diusulkan } \\
\hline Pada sistem yang berjalan & Pada sistem yang diusulkan \\
saat ini, kepala seksi harus & kepala seksi tidak harus \\
menginput data jadwal dan & mencetak buku kalender dan \\
\hline
\end{tabular}


tugas secara manual sehingga

memerlukan banyak waktu. menginputnya secara manual

karena sudah terkomputerisasi.

\section{Information (informasi)}

Informasi merupakan komoditas terpenting bagi seorang pengguna akhir pada suatu sistem dalam pengambilan keputusan. Dengan sistem informasi yang baik maka akan menghasilkan informasi yang bermanfaat serta dapat mendukung dalam menanggapi masalah dan peluang yang ada.

Tabel II. Information (informasi)

\begin{tabular}{|l|l|}
\hline Sistem lama & \multicolumn{1}{|c|}{ Sistem yang diusulkan } \\
\hline Pada sistem yang lama, kepala & Pada sistem yang diusulkan \\
seksi sering melakukan & kepala seksi dapat langsung \\
kesalahan saat proses & mengubah data jadwal tugas, \\
penginputan jadwal, sehingga & ketika terjadi kesalahan \\
kepala seksi harus membuat & pengimputan. \\
ulang kalender tersebut. & \\
\hline
\end{tabular}

\section{Economy (ekonomi)}

Sistem yang ada saat ini masih membutuhkan biaya, dilihat dari segi ekonomisnya sistem yang ada saat ini masih mengeluarkan biaya yang tidak sedikit setiap akan melakukan pencatatan data aset, sehingga sistem yang sedang berjalan saat ini masih kurang ekonomis.

Tabel III. Economy (ekonomi)

\begin{tabular}{|l|l|}
\hline Sistem lama & \multicolumn{2}{|c|}{ Sistem yang diusulkan } \\
\hline Pada sistem lama kepala seksi & Pada sistem yang diusulkan \\
harus mencetak lagi buku & kepala seksi tidak lagi untuk \\
kalender ketika terjadi & mencetak buku kalender \\
kesalahan pengimputan jadwal & penjadwalan dan dapat meminim \\
tugas & biaya pengeluaran. \\
\hline
\end{tabular}

\section{Control (Kontrol)}

Pengendalian dalam sistem sangat diperlukan, yaitu digunakan untuk meningkatkan kinerja sistem, mencegah atau mendeteksi penyalahgunaan atau kesalahan sistem serta untuk menjamin keamanan data dan informasi.

Tabel IV. Control (kontrol)

\begin{tabular}{|l|l|}
\hline \multicolumn{1}{|c|}{ Sistem lama } & \multicolumn{2}{c|}{ Sistem yang diusulkan } \\
\hline Pada sistem yang lama kepala & Pada sistem yang diusulkan \\
seksi tidak dapat langsung & kepala seksi dapat langsung \\
melihat laporan tugas sebelum & laporan tugas yang diinput oleh \\
pegawai melapor langsung & pegawai dan tidak harus \\
pada kepala seksi. & menemui langsung kepala seksi. \\
\hline
\end{tabular}

\section{Effisiency (efisiensi)}

Terdapat perbedaan antara efisiensi dengan ekonomis. Ekonomis berkaitan dengan sesedikit mungkin jumlah sumber daya yang digunakan sehingga menghasilkan keuntungan, sedangkan efisiensi berhubungan dengan bagaimana sumber daya yang ada dapat digunakan dengan sebaik dan sehemat mungkin dengan pemborosan/biaya yang paling minimum.

Tabel V. Efficiency (efesien) 


\begin{tabular}{|l|l|}
\hline Sistem lama & \multicolumn{1}{|c|}{ Sistem yang berjalan } \\
\hline Pada sistem lama masih kurang & Pada sistem yang diusulkan \\
efisien karena kepala seksi harus & kepala seksi dapat langsung \\
terlebih dahulu mencetak buku & menginput jadwal tugas dan \\
kalender ketika akan membuat & dapat mengedit ketika terjadi \\
jadwal tugas. & kesalahan penginputan. \\
\hline
\end{tabular}

6. $\quad$ Service (pelayanan)

Pelayanan yang diberikan sangat mendukung dalam peningkatan kinerja pegawai.

Tabel VI. Service (pelayanan)

\begin{tabular}{|l|l|}
\hline Sistem lama & \multicolumn{1}{|c|}{ Sistem yang diusulkan } \\
\hline pegawai harus menunggu & Pada sistem yang diusulkan \\
jadwal tugas yang baru & pegawai tidak harus menunggu \\
ketika kepala seksi terjadi & kepala seksi memberikan jadwal \\
kesalahan dalam proses & tugas yang selesai dibuat karena \\
penginputan jadwal tugas. & sistem sudah terkomputerisasi . \\
\hline
\end{tabular}

\subsection{Metode Perancangan Sistem}

Pada metode ini, Dalam membuat rancangan sistem, peneliti menggunakan metode yang menyarankan sebuah pendekatan yang sistematis dan sekuensial melalui tahapan - tahapan yang ada pada SDLC (Sytem Development Life Cycle) untuk membangun sebuah perangkat lunak. Penulis menggunakan metode perancangan dengan Unified Modelling Language (UML[8]), Class Diagram, pembuatan database dan disesuaikan berdasarkan elisitasi tahap I, elisitasi tahap II, elisitasi tahap III dan final draft elisitasi. Sedangkan dengan kebutuhan software bahasa pemrograman yang digunakan yaitu PHP Hypertext Preprosesor (PHP) dengan menggunakan database $M y S Q L$ yang dipergunakan untuk merancang sistem berdasarkan kebutuhan dari stakeholder.

\subsection{Metode Pengembangan throw-away prototyping}

Dalam penelitian ini penulis menggunakan metode throw-away prototyping. Dengan menggunakan metode ini, spesifikasi awal dari sistem sudah dapat diketahui di awal, sehingga proses prototyping ini ditujukan untuk mengurangi resiko kebutuhan yang tidak terpenuhi.

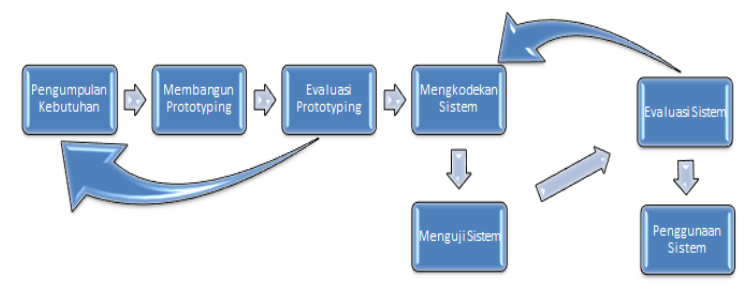

Gambar 1. Proses throwaway prototyping[9]

Tahapan Metode Prototyping[10]:

1. Pemilihan Fungsi. Mengacu pada pemilahan fungsi yang harus ditampilkan oleh prototyping. Pemilahan harus selalu dilakukan berdasarkan pada tugas-tugas yang relevan yang sesuai dengan contoh kasus yang akan diperagakan.

2. Penyusunan Sistem Informasi. Bertujuan memenuhi permintaan kebutuhan akan tersedianya prototype.

3. Evaluasi.

4. Penggunaan selanjutnya. 


\section{Hasil dan Pembahasan}

4.

3.1 Rancangan Sistem dengan Unified Modelling Language (UML)

1. Use Case Diagram Sistem

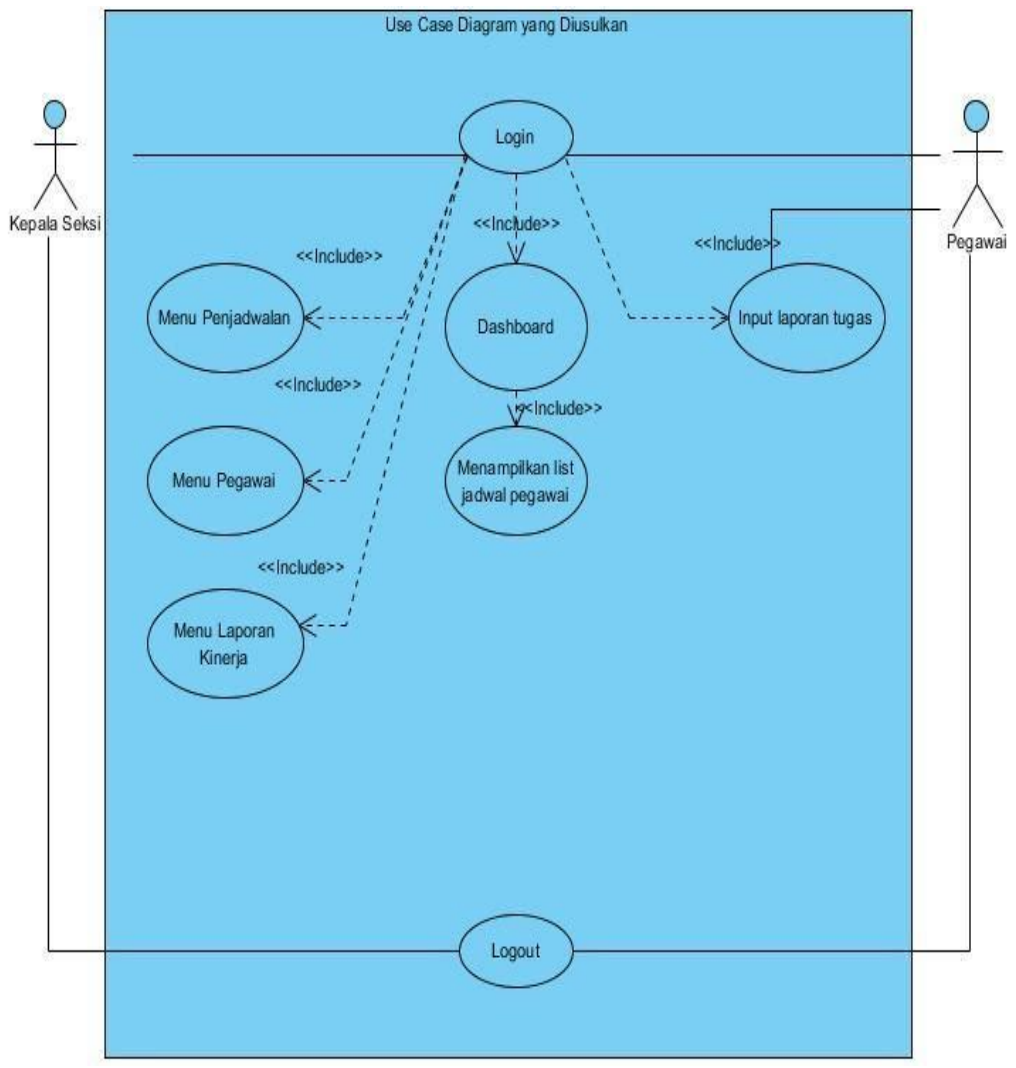

Gambar 2. Usecase Diagram Sistem

Berdasarkan gambar 2. Use Case Diagram diatas terdapat: System yang mencakup seluruh sistem yang berjalan pada Badan Pust Statistik Kota Tangerang. 2 Actor, yang melakukan kegiatan, yaitu: Kepala Seksi dan Pegawai. 8 use case, yang merupakan kegiatan yang dilakukan oleh actor-actor. Dan 6 Include.

2. Activity Diagram Sistem: Kepala Seksi

3. 


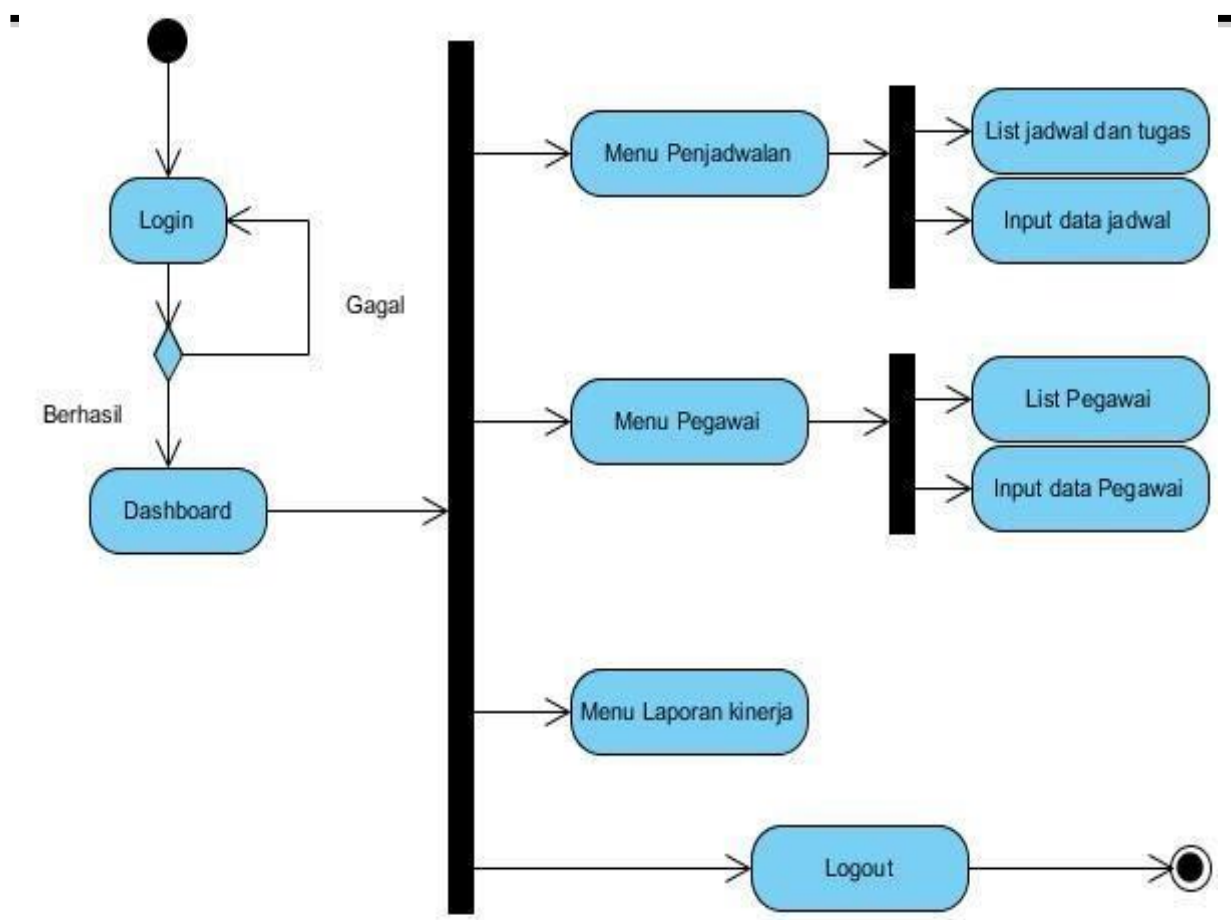

Gambar 3. Activity Diagram Sistem Kepala Seksi

Berdasarkan gambar 3 Activity Diagram diatas terdapat: 1 Initial Node sebagai objek awal. 1 decision node. 10 action, yang mencerminkan suatu eksekusi dari aksi. 3 Fork Node yang mencerminkan penggabungan action. Dan 1 final node sebagai akhir objek.

4. Activity Diagram Sistem: Pegawai 


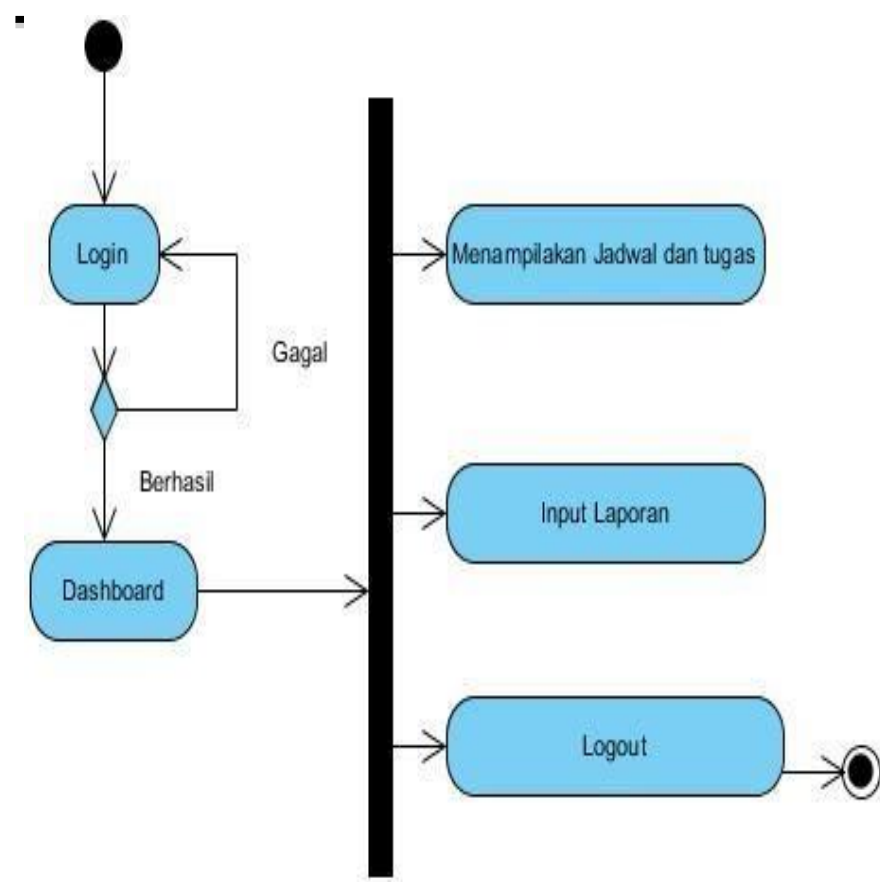

Gambar 4. Activity Diagram Sistem Pegawai

Berdasarkan gambar 4 Activity Diagram diatas terdapat: 1 Initial Node sebagai objek awal. 1 decision node. 5 action, yang mencerminkan suatu eksekusi dari aksi. 1 Fork Node yang mencerminkan penggabungan action. Dan 1 final node sebagai objek akhir.

5. Sequence Diagram Sistem: Kepala Seksi

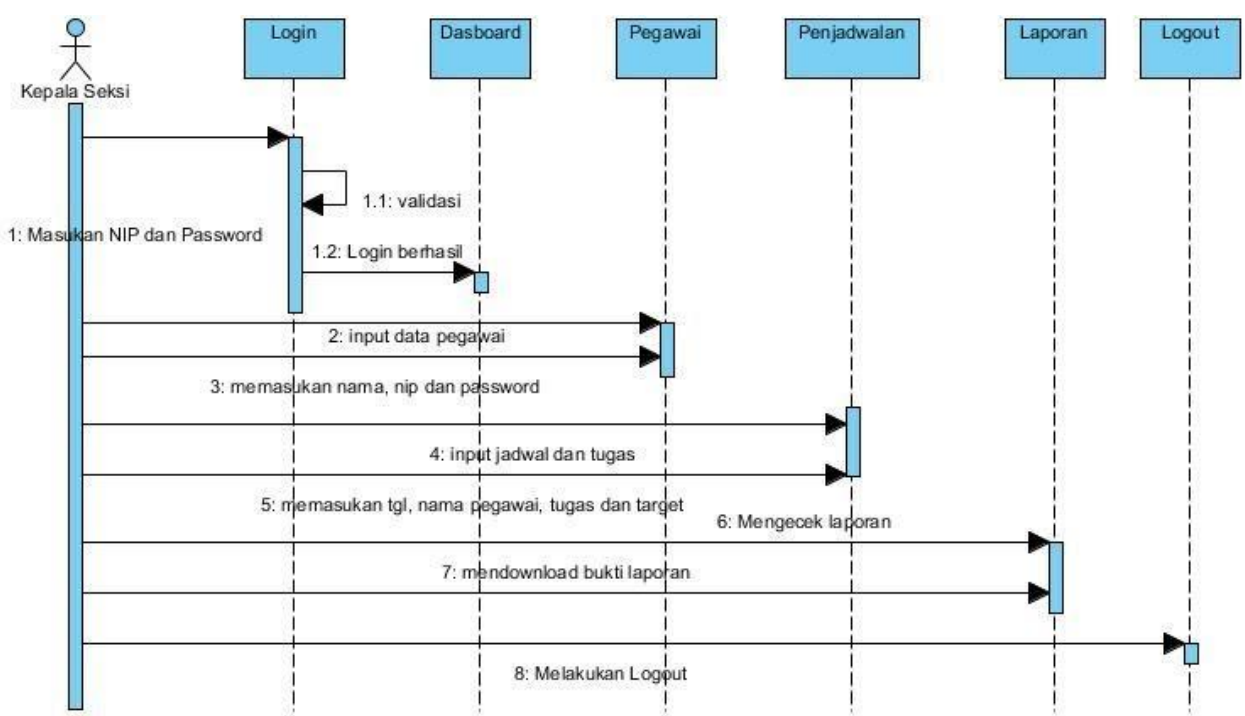

Gambar 5. Sequence Diagram Sistem Kepala Seksi

Berdasarkan gambar 5 Sequence Diagram sistem diatas terdapat: 1 actor, yang melakukan kegiatan yaitu Kepala Seksi. 6 lifeline, antar muka yang saling berinteraksi dan 5 messages, yaitu komunikasi objek yang dilakukan oleh actor.

6. Sequence Diagram Sistem: Pegawai 


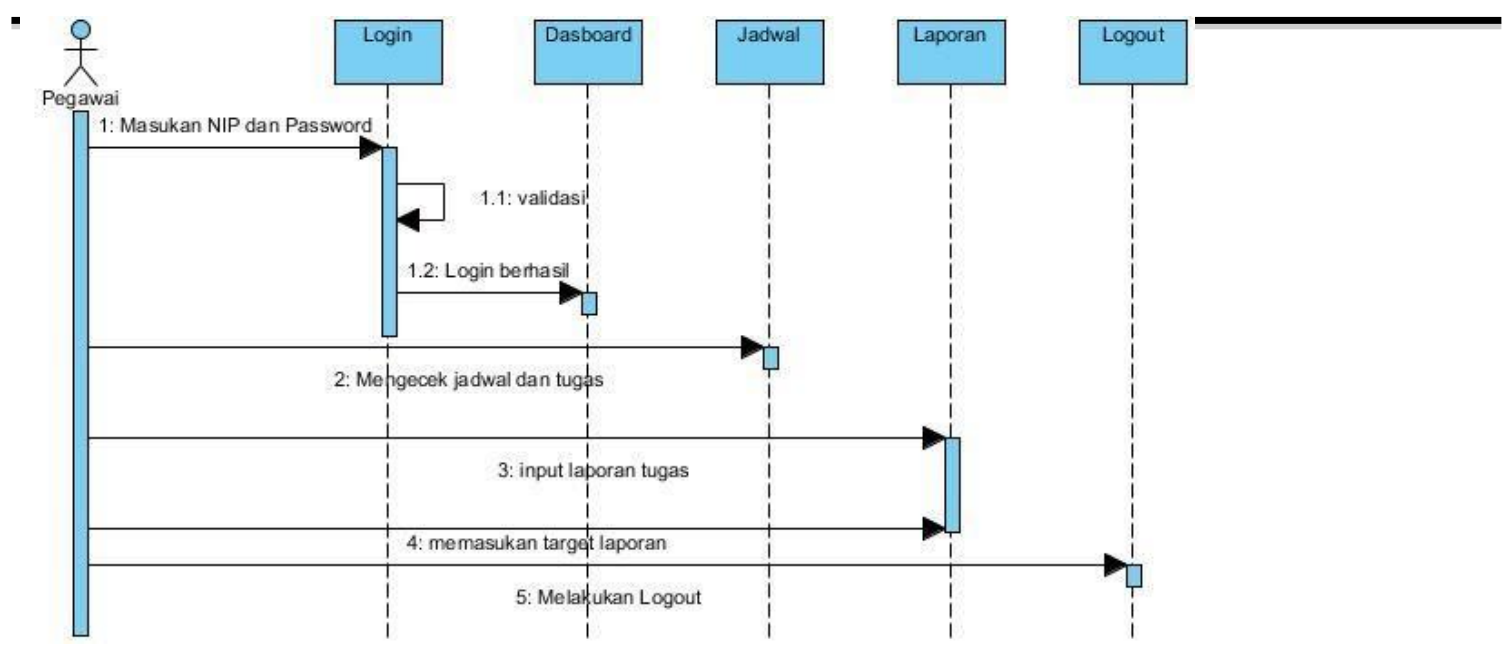

Gambar 6. Sequence Diagram Sistem Pegawai

Berdasarkan gambar 6. Sequence Diagram sistem diatas terdapat: 1 actor, yang melakukan kegiatan yaitu pegawai. 5 lifeline, antar muka yang saling berinteraksi dan 4 messages, yaitu komunikasi objek yang dilakukan oleh actor.

\subsection{Perancangan Database: Class Diagram}

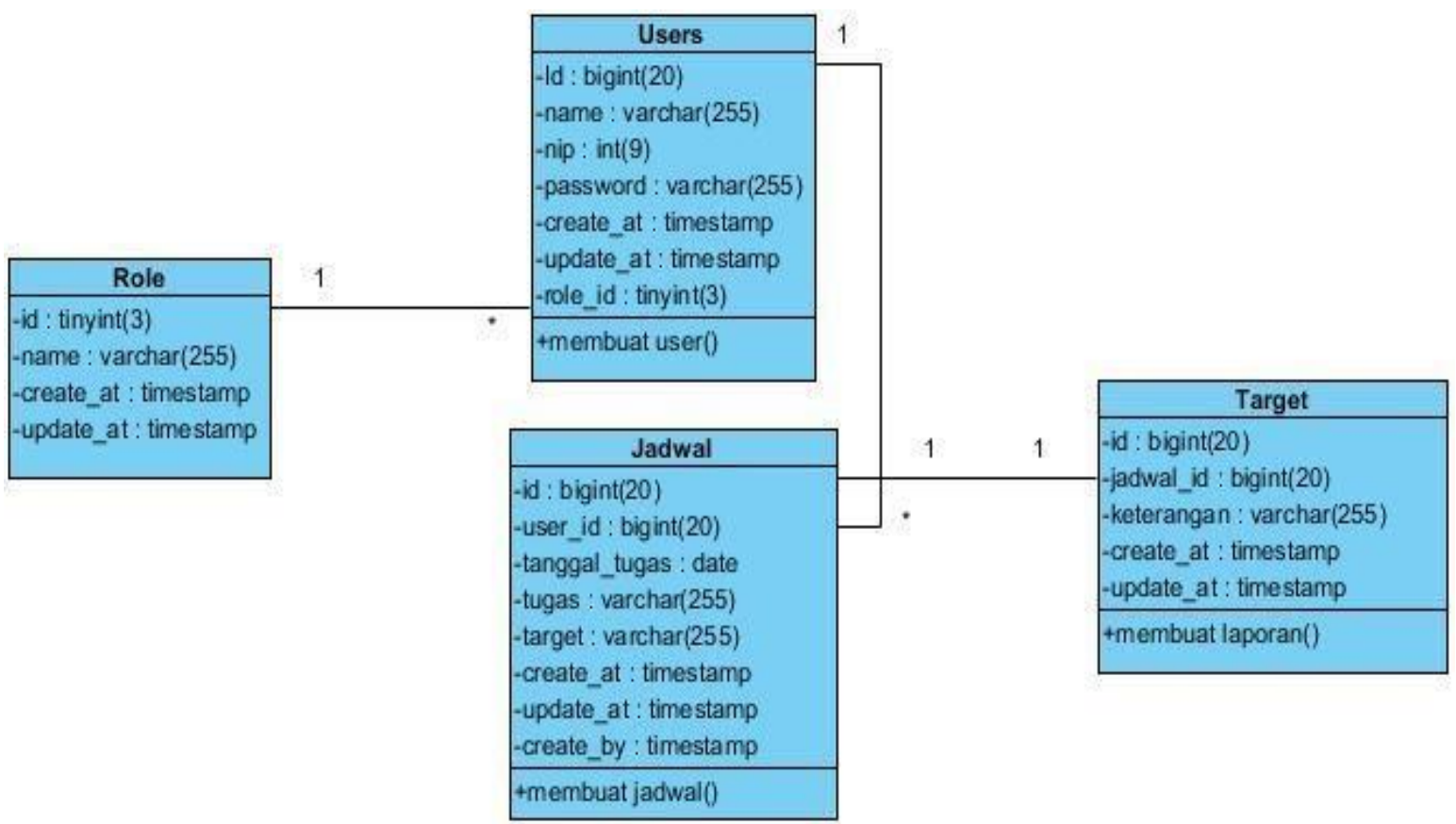

Gambar 7. Class Diagram

Berdasarkan gambar 6. Class Diagram, rancangan class diagram dapat dijelaskan sebagai berikut: 4 Class, himpunan dari objek berbagai atribut diantaranya, Role, Users, Jadwal, Target. Dan 3 multiciply, hubungan antara objek satu dengan objek lainnya yang mempunyai nilai.

3.3 Implementasi Sistem Penjualan dan Persediaan Barang

1. Tampilan Login 


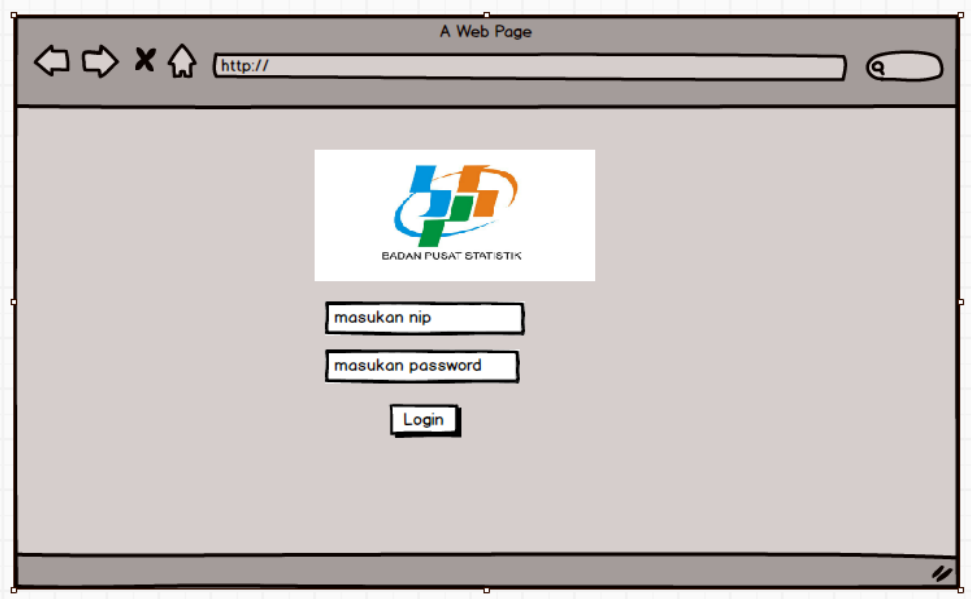

Gambar 8. Tampilan Login Sistem

Berdasarkan gambar 8. tampilan login sistem diatas dalam form login terdapat field Username dan Password. Hal ini berguna sebagai hak akses pengguna atau EndUser tertentu untuk mengakses sistem guna menghindari terjadinya perubahan data oleh pihak yang tidak bertanggung jawab.

2. Tampilan Halaman Dashboard
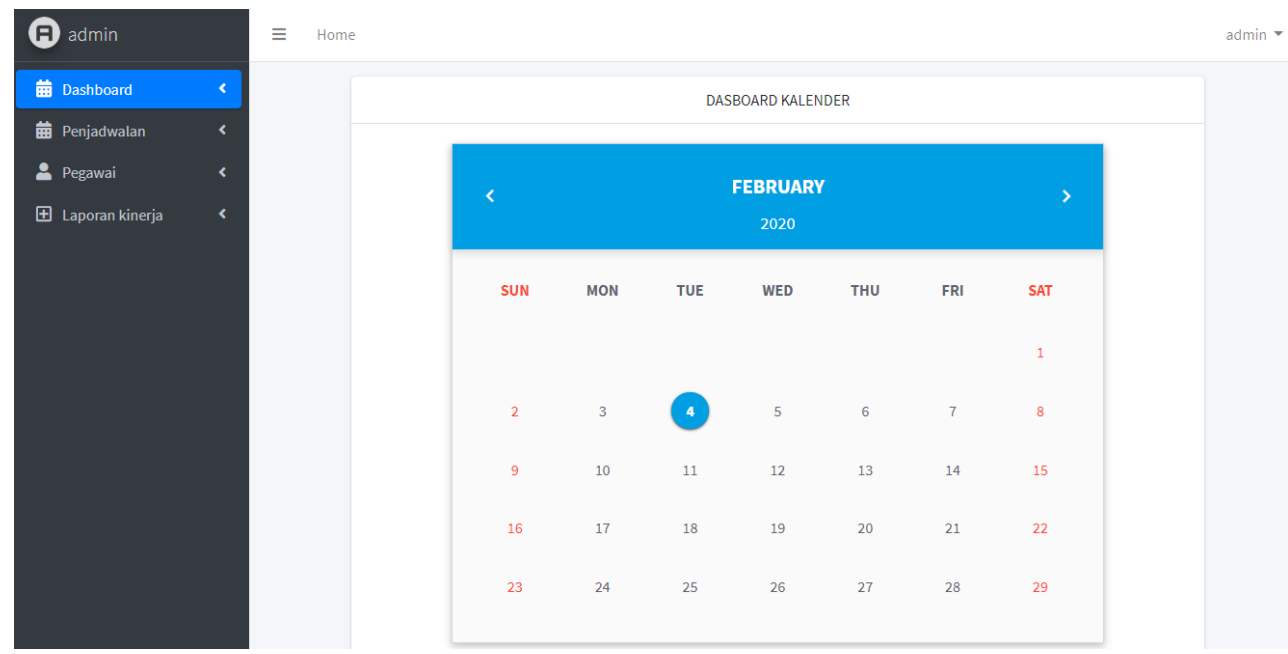

Gambar 9. Halaman Dashboard

Berdasarkan Gambar 9. Halaman Dashboard Kepala Seksi dan Admin menginput tugas harian Lapangan Pegawai berdasarkan tanggal dan lokasi yang telah ditentukan.

3. Tampilan Penjadwalan Tugas 


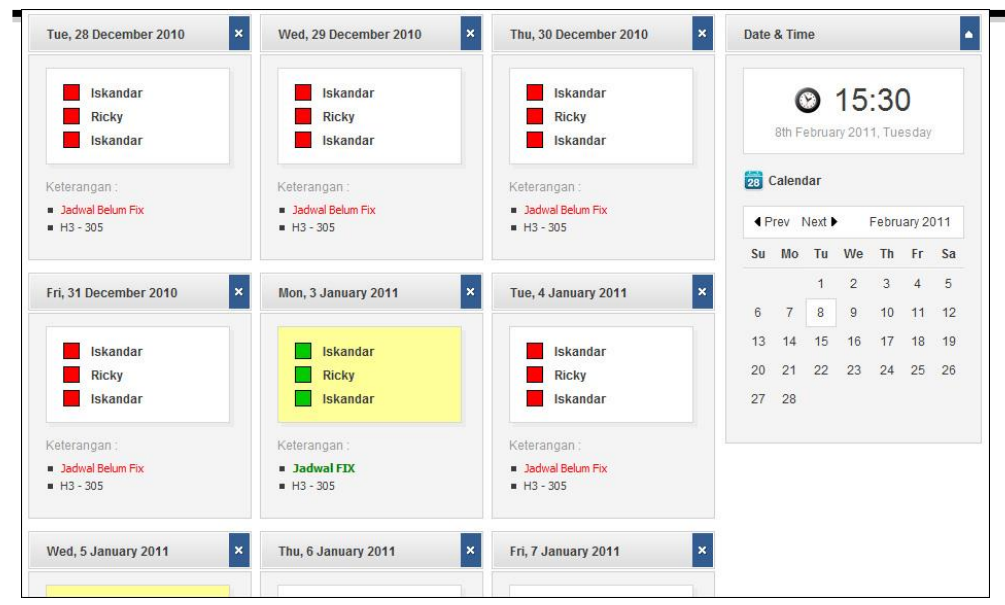

Gambar 10. Penjadwalan Tugas Pegawai

Berdasarkan Gambar 10 diatas, tugas harian lapangan pegawai sudah diinput oleh admin dan kepala seksi yang nanti laporan pegawai dapat di input oleh pegawai atas tugas lapangan pewagai yang telah dilaksanakan.

4. Tampilan Laporan Kinerja pegawai

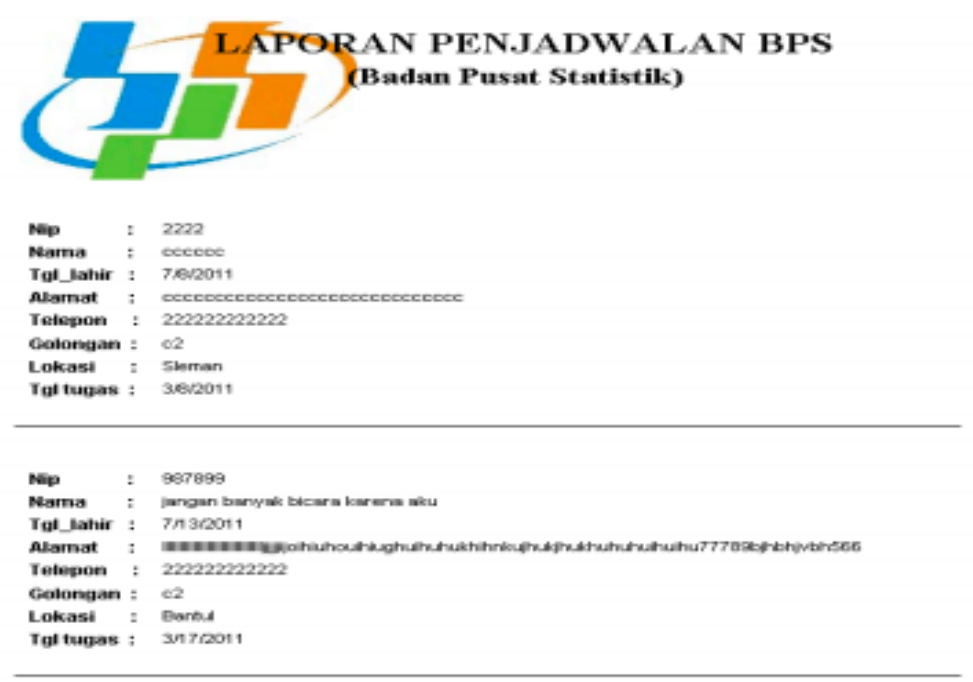

Gambar 11. Laporan Kinerja Pegawai

Berdasarkan Gambar 11 diatas merupakan laporan kinerja pegawai yang telah melaksanakan tugas lapangan yang telah dijadwalkan oleh admin dan kepala seksi.

\section{Kesimpulan}

Berdasarkan uraian sebelumnya serta analisis yang dilakukan oleh penulis mengenai sistem yang berjalan di Badan Pusat Statistik Kota Tangerang, maka penulis dapat mengambil kesimpulan sebagai berikut: Dengan adanya sistem penjadwalan ini dapat mempermudah Kepala seksi dalam mengatur dan merencanakan penjadwalan tugas bagi para pegawai.

Dengan adanya sistem penjadwalan berbasis web kepala seksi tidak harus mencetak lagi buku kalender jadwal tugas.

Dengan adanya sistem penjadwalan berbasis web dapat mengganti sistem manual yang masih digunakan di Kantor Badan Pusat Statistik Kota Tanggerang. 
[1] F. Alfiah et al., "PERANCANGAN SISTEM E - COMMERCE UNTUK PENJUALAN PAKAIAN PADA TOKO A \& S," vol. 6, no. 1, pp. 70-81.

[2] R. Aprianto, Wulandari, and N. Hafifah, "Pengembangan Aplikasi Web Mobile Penjadwalan Tugas Aparatur Desa Untuk Meningkatkan Layanan Masyarakat," J. Teknol. Komput. dan Sist. Inf., vol. 01, no. 03, pp. 81-86, 2018, [Online]. Available: http://ojs.stmikpringsewu.ac.id/index.php/jtksi/article/view/663.

[3] F. S. Sulaeman and M. F. F. Nurjaman, "Aplikasi Penjadwalan Dan Booking Online Menggunakan Teknologi Android Webview," Media J. Inform., vol. 11, no. 2, p. 8, 2020, doi: 10.35194/mji.v11i2.1033.

[4] D. M. Informatika, F. Teknik, U. N. Surabaya, T. Informatika, F. Teknis, and U. N. Surabaya, "Rancang Bangun Aplikasi Penjadwalan Skripsi dan Tugas Akhir Berbasis Web Menggunakan Framework Laravel RANCANG BANGUN APLIKASI PENJADWALAN SKRIPSI DAN TUGAS AKHIR BERBASIS WEB MENGGUNAKAN FRAMEWORK LARAVEL Jihad Satrio Utama I Kadek Dwi Nuryana Abstrak Rancang Bangun Aplikasi Penjadwalan Skripsi dan Tugas Akhir Berbasis Web Menggunakan Framework Laravel," pp. 110.

[5] D. Aulianida, S. I. Liestyasari, and S. R. Ch, “済無No Title No Title,” J. Chem. Inf. Model., vol. 53, no. 9, pp. 1689-1699, 2019.

[6] D. Marsudi, "Politeknik Negeri Sriwijaya 4," Pembangkitan Energi List., vol. 7, no. 1, pp. 4-31, 2016.

[7] Sunu Prasetyo, "ANALISIS DAN PERANCANGAN SISTEM INFORMASI PENJADWALAN PEGAWAI DI BPS PROVINSI DAERAH ISTIMEWA YOGYAKARTA," 2011. AMIKOM Yogyakarta.

[8] P. Seminar et al., "Prototype Pengembangan Sistem Informasi Koperasi Simpan Pinjam Pada Sekolah XYZ Menggunakan Metode Throwaway Prototyping Development," no. September, pp. 34-46, 2019.

[9] V. No, D. Meilantika, D. Meilantika, and D. Meilantika, "RANCANG BANGUN SISTEM INFORMASI ADMINISTRASI MENGGUNAKAN METODE THROWAWAY PROTOTYPING DEVELOPMENT PADA SULTAN-SPORT," vol. 2, no. 2, pp. 114-121, 2017.

[10] A. Setiadi and F. Alfiah, "Sistem Penjualan Spare Part Toko Ajm Motor Menggunakan Ci Berbasis Arsitektur Mvc," Simetris J. Tek. Mesin, Elektro dan Ilmu Komput., vol. 7, no. 2, p. 575, 2016, doi: 10.24176/simet.v7i2.770. 